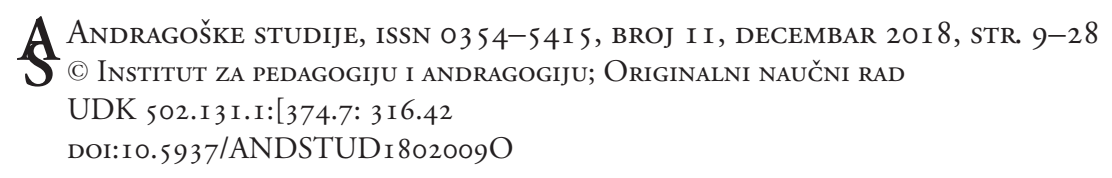

Violeta Orlović Lovren ${ }^{1}$

Faculty of Philosophy, University of Belgrade

\title{
Learning for Sustainability through Community Involvement in Protected Area Governance
}

\begin{abstract}
The paper explores community involvement (CI) in protected area (PA) governance as an opportunity to learn, share knowledge and decision making power and contribute to sustainability starting from a local level, through regional and national and up to a global level. In addition to a brief review of the relevant theoretical and policy approaches to learning for sustainability in the context of the local community, this paper comprises a secondary analysis of the results of an empirical research on community involvement in PA governance. The research was carried out under the framework of the project Protected Areas for Nature and People (PA4NP), launched by the WWF Adria. The methodology uses a combination of a qualitative and a quantitative approach. The results of the research clearly indicate that there is an overall gap in assessment between protected areas and community representatives, and that there is an obvious need for improvement in their mutual communication and collaboration. Based on these findings, the needs and opportunities for learning in that process are discussed within the local context and global development trends.
\end{abstract}

Key words: learning, sustainability, local community, protected area, governance.

\section{Introduction}

The 2030 Agenda for Sustainable Development is inviting us to join forces and take "bold and transformative steps which are urgently needed to shift the world on to a sustainable and resilient path" (UN, 2015, p. 3). Within the global de-

\footnotetext{
${ }^{1}$ Violeta Orlović Lovren, PhD is an associate professor at the Faculty of Philosophy, University of Belgrade (violeta.orlovic@f.bg.ac.rs).
} 
velopment framework and the formulation of sustainable development goals (SDG), education and learning are seen as a major support to these transformative processes, towards inclusion of all and creation of effective partnerships in every segment of life.

By analysing the transformative potential of learning from the adult education perspective, this paper examines the relationship between protected areas and the local community in order to identify the needs and opportunities that could improve community involvement in protected area governance. By broadening our focus, we actually examine one of the possible pictures within a wider network of interwoven relationships between nature (symbolized by protected areas) and society (specific local community context). As often emphasized, learning creates one of the strongest links between people and their environment. However, this interaction cannot be considered linear. As observed by Scott and Gough, learning can take place "...by individuals, who may change their ideas about society, environment and change; by society, as it adapts in planned and unplanned ways and by the environment, in the sense that it too adapts in response to human activity" (Scott and Gough, 2003, p. 44). The 'paradigm shift' in our relations with nature requires appreciation of these complex and mutual influences, and again, learning to reflect upon experiences within an individual, social and natural context.

In protected area (PA) circles, the paradigm shift happened with the introduction of the concepts of collaborative management and co-management, based on experience and supported by findings demonstrating that the level of local community participation in PA management plays a significant role in the long-term success of conservation strategies for PAs (Andrade and Rhodes, 2012).

The emerging approaches are inspired by 'community-based conservation', where local people are not seen as a 'threat to nature', but valuable sources of traditional knowledge and experience in preserving biodiversity and managing resources in a sustainable way (Andrade and Rhodes, 2012). The introduction of a sustainable development concept, global policy, relevant international organizations and bodies is further shifting the focus from protected area management to governance, looking at both 'parks and people' and the ways to support these local partnerships towards accomplishing SDGs. Learning, education and capacity development are largely recognised as powerful mechanisms of strengthening these relationships and improving the transformative potential of community towards sustainability. 


\section{Learning for sustainability - from a global to a local community}

In accordance with the general call for transformation, global policy defines education for sustainable development (ESD) as "the approach and the process", with the "...potential to empower learners to transform themselves and the society they live in by developing knowledge, skills, attitudes, competences and values required for addressing global citizenship and local contextual challenges of the present and the future" (UNESCO, 2014, p. 1). Countries are encouraged to 'reorient' their education systems, while teachers are invited to rethink their practice having in mind recommendations directed toward development of the key competences for sustainability: systems thinking, anticipatory, normative, strategic, collaboration, critical thinking, self-awareness as well as competency for integrated problem-solving (UNESCO, 2017, p. 10). From the perspective of learning as a transformative process, we would agree with Wals, that 'competence' should not be considered "as an analytical term that cuts up human behaviour into smaller pieces", but rather "...as a relational, contextual and emergent property" (Wals, 2015, p. 11). At the level of global policy, 'citizens for the $21^{\text {st }}$ century' are invited not only to "deal with today's complex challenges", but also to look at "the big picture" (UNESCO, 2017, p. 11), striving to relate not only to individual SDGs, but also to their mutual relations.

As seen by Bonnet, sustainability is a 'frame of mind' (2002, p. 12) and in order to rethink assumptions which led previous development towards social, economic and environmental crisis, education should play important transformative role. Learning for sustainability - within the formal and nonformal education or informally undertaken by individuals and groups (incidentally or as a result of intention and conscious choice), should be then supported by "new critical, futures-oriented and inclusive pedagogies" (Tilbury, 2011, according to Kapitulcinova et al, 2015). One of 'pedagogies' of that kind is suggested by authors of the 'transformative sustainability learning' (TSL), as “.... series of learning objectives corresponding to cognitive (head), psychomotor (hands) and affective (heart) domains of learning that facilitate personal experience for participants resulting in profound changes in knowledge, skills and attitudes related to enhancing ecological, social and economic justice." (Sipos, Battisti \& Grimm, 2008, p. 68).

Learning for sustainability often brings experiences and touches upon values that may deeply affect our everyday life and our previous beliefs and assumptions. No matter how small, 'discoveries' during that process might influence 
changes in our perspectives and open up entirely new views towards relations between us and other humans or between humans and nature. Therefore, it is not surprising that transformative learning theory exerts a significant influence on authors dealing with sustainability, who even find that it offers "...an explanation of the learning process underlying the journey to sustainable living" (Leal Filho, Raath, Lazzarini, Vargas, de Souza, Anholon, Quelhas, Haddad, Klavins \& Orlovic, 2018, p. 287). As widely agreed, the outcome of such a process should not be reduced to "behavioural modification in the pursuit of sustainability"; it should rather lead towards "independent and critical thinking, stimulating learners to become active citizens" (Jensen \& Schnack; Breiting; Jóhannesson et al., according to Van Peock \& Vanderabeele, 2014, p. 222).

There is obviously considerable agreement between global policy and the majority of authors regarding the transformative potential of learning and similarity of models of competences that should guide education for sustainability. However, difficulties always arise when the question "how" is concerned. In the context of our research, "how" refers to the ways adults may be stimulated and facilitated in undertaking such a transformation within community learning towards sustainability. What could happen if they would not face or recognize their 'disorienting dilemma' as a "discrepancy between what a person has always assumed to be true and what has just been experienced" (Cranton, 2002, p. 66) or are not provided with any guidance through 'articulating assumptions' or 'critical self-reflections', so that they could reach the highest stage of transformative learning rethinking their thoughts and actions (Mezirow, 1991). Critically reflecting on transformative learning theory, Newman (2012) argues that it might not be new 'kind' of learning, but rather the 'degree' only - referring to the intensity of change taking place within the learning process. Claiming that every learning process - if effective - brings opportunity for growth and increased awareness, he argues that we should simply call it good, rather than transformative, learning (Newman, 2012, underlined by V.O.L.).

Even if the term transformation is seen as too strong, overused or describing highly demanding learning and teaching goals, the key is in our opinion, not in focusing on results or attributes only ('good', 'quality' learning), but rather on the process. The transformation of perspectives, as noted “...can occur slowly through gradual changes in attitudes and beliefs or through a shattering experience, a 'disorienting dilemma'" (Blewitt, 2006, p. 6). It can happen at a personal or at the social level. Even if there is no support of a facilitator or teacher as can often happen within learning in a community - self-reflection might be 
prompted by discussion with neighbours, by the movie - or facilitated by social movements (Blewitt, 2006).

Considering community as a "fundamental unit of sustainability", authors even state that "there is no such a thing as sustainability for individuals" (Jensen, 2014 , p. 31). The relational dimension of learning for sustainability may also be understood in the light of the social constructivists' view on the process of interactions enabling 'co-creation' of learning opportunities and outcomes. Its practical and context-specific nature may be as well recognized within the concept of 'situational learning' seen as a kind of 'apprenticeship' where community practice may be considered as a specific knowledge of that particular social entity (Woolfolk, Hughes \& Walkup, 2014).

Another important aspect of the local context for learning towards sustainability should be taken into consideration: abstract by its nature, the concept of sustainability may become more understandable when viewed at the local level. As noted"...sustainable community development can be the most effective means of demonstrating the possibility that sustainability can be achieved at a broader scale" (Bridger \& Luloff, according to Blewitt, 2006). As it is well known in adult education, connectivity with real life is tremendously important and therefore, starting from where people are and building on that while motivating them for active engagement (Clover, Jayme, Fallen \& Hall, 2010) should be a necessary part of the approach to learning for sustainability.

While the term connectivity usually refers in nature conservation to the connection between ecosystems and protected/non protected areas, adult educators should be involved in stimulating people to reflect on their attitudes and feelings towards environment, rethinking their connectivity to "the rest of nature" (Clover et al, 2010). Connectivity may also be understood in terms of relations between teaching young people and adults, assuring development of their higher order abilities and their habits to reflect upon their perspectives and actions. It is also, and in particular when considering learning through community involvement, about 'co-creating' of enabling social environment, as a contribution to positive 'climate changes' with necessary support in legal and decision making procedures provided in the wider society.

Assuring quality learning and education for sustainability in such a climate might still not be enough for the shift from "I know" to "I care" (Howard, 2012). Looking for powerful enough drivers for community to get involved into dealing with 'matters of concern' (Van Poeck \& Vandenabeele, 2014), in particular when there is a lack of governments assistance, authors promote the model of 'energetic society' and its high transformative potential: "Such actors are articulate, 
autonomous citizens, civil society initiatives, self-organized farmers, cities and innovative companies that take action in highly diverse development contexts... While in many countries, governments are retreating from the direct provision of public goods...the energetic society steps in and provides public services ranging from the creation of more green areas through local energy provision to the provision of knowledge and information, for instance through citizen science" (Hajer, Nilsson, Raworth, Bakker, Berkhout, deBoer, Rockström, Ludwig \& Kok, 2015, p. 1656).

Citizens often cannot - or do not want to - develop abilities to express and exercise their own "science", through the formal education systems or within some organized social movement. Adult educators might play a significant role in supporting them while gaining 'skills for sustainable communities', such as "...learning how to lead and facilitate...how to listen, how to communicate empathically and clearly and how to get on with others..." (Blewitt, 2006, p. 152) or in developing sustainabilities (Wals, 2015). However, the point is in the approach they select in designing and implementing such programs - not only in terms of understanding adult learning, but also the concept of sustainability. Instead of considering sustainability as one general, 'fixed-end goal' (Wals, 2015) which would lead towards the development of disciplined citizens, the approach to transformative community learning requires seeing it “...as an emergent and continuously to be redefined property", which brings larger "range of action possibilities or pathways to sustainability" (Wals, 2015, p. 10).

In the academic literature concerned with the role of adult education in community engagement, authors differ in opinion regarding the efforts oriented towards socialization or transformation; while the first "concern the learning of people to take up roles in different communities", the second refers to the "way people actively and democratically respond to matters of injustice" (Wildemeersch $\&$ Fejes, 2018, p. 134). While finding its way to meet the needs of community members in these transformations, adult education should support redefining concepts of community and democratic participation (Vandenabeele, Reyskens \& Wildemeersch, 2011) at a general level, as well as at the context specific level.

The diversity of characteristics and dynamic of relations between local communities and protected areas require educational, institutional and policy support which would contribute to the 'co-creation' of climate for constant mutual re-definition of meanings and interactions, thus finding authentic ways to develop toward sustainability in accordance with their needs and perspectives. Initiating the assessment of community involvement in PA governance was intended to contribute to that. 


\section{Local community and protected area governance}

In more than a hundred years of history of designated PAs, since they were first formally established in 1872 in Yellowstone, countries and governments around the world have adhered to a "conventional and exclusionary approach" (Andrade $\&$ Rhodes, 2012), putting main focus on natural values, thus separating those areas from people and their communities.

It contributed to increasing conflicts between PAs and people, whose previous practices or even ownership of the land were disrupted. In its traditional forms, the management of PAs was first of all the responsibility of assigned government (local, regional, national) bodies or organizations. It was increasing the distance between local people and protected areas, as a reflection and continuation of "...the ontological and ideological separation of nature and culture" (Sarkki, Rantala \& Karjalainen, 2015, p. 300).

The impacts of the emerging concept of sustainability influence the redefinitions of the PA management approach and practice. This is particularly evidenced in paying higher attention to economic and social development and benefits that protected area may have for local community, as well as to mutual responsibility for conservation and development. "The changing paradigm of protected area (PA) from romantic vision of 'exhibition of untouched nature' to potential models of sustainability, calls for different distribution of responsibilities, shifting it from PA staff and managers only to partnerships with large stakeholder community and society" (Orlovic Lovren, 2013, p. 87).

As noted, these processes are consistent with broader trends and concepts of active citizenship and participation in all areas of social life, and the "...move from direction by government to a more inclusive governance involving multiple parties" (Dovers, Feary, Martin, McMillan, Morgan \& Tollefson, 2015, p. 415). While management is about "what should be done", governance of PAs is about "...interactions among structures, processes and traditions that determine how power is exercised, how decisions are taken on issues of public concern, and how citizens or other stakeholders have their say" (Lockwood, Worboys \& Kothari, 2012, p. 116, underlined by V.O.L.).

The International Union for Conservation of Nature and other relevant organizations advocate promoting collaborative management as a desired democratic and socially just practice, in particular from 1990s, for co/management models as the highest forms of collaboration between PA managers and stakeholders - as partners sharing rights and responsibilities for management and governance. Various types of governance models are now officially recognized, 
including traditional and indigenous communities as co-managers (Lockwood et al, 2012).

In addition to previous responsibilities, PA managers are now facing new challenges and require more developed 'people skills' and sustainability competences. Even if not clearly stated in their job descriptions, participatory approach is required, as a result of the 'shifted answer' to the question 'whose job is conservation' (Worboys, Lockwood, Kothari, Feary \& Pulsford, 2015). A recent study carried out by the University of Queensland on protected area management effectiveness revealed that "three of the top seven significant variables relate to social policy and the cohesion of intention between professional managers and the society in which the protected area is located" (according to Worboys et al, 2015, p. 125).

Despite its wide acceptance and growing elaboration in research and literature, participatory PA management and governance is difficult to put into practice. The assessments made in Carpathian countries in 2009-2010, as well as the scorecard analysis again carried out by the WWF, demonstrate that there was no remarkable progress in practicing participatory governance and stakeholder involvement in that period: even in areas where multi-stakeholder bodies were established, it was not really done in an inclusive and functional manner in the majority of the places (Iontja, 2013). Recently defined by legal regulations in some countries within the Dinaric region (Montenegro, Serbia, Macedonia), establishment of 'stakeholders forums' is taking place, although it still needs to develop into a truly engaging process, with sharing of decision making power between all the actors involved. One of the necessary preconditions for success is strengthened capacity and enhanced cooperation of all participants.

It is not surprising that knowledge and learning are also viewed as key factors in those processes in the global policy documents. Quality and inclusive education for all, as defined within the SDG goals, and in particular goal four and its target seven, advocating for "education for sustainable development and sustainable lifestyles, human rights, gender equality, promotion of a culture of peace and non-violence, global citizenship and appreciation of cultural diversity and of culture's contribution to sustainable development" (UN, 2015, p. 21), is considered one of the most important targets"...that provide opportunities for the further development of protected areas or have implications for the ways in which protected areas will be managed in the future" (Dudley, Ali \& MacKinnon, 2017, p. 1).

Along with a wide recognition of rights of traditional and local communities in PA governance, the value of their knowledge and practices in preserving biodiversity and in running protected areas in a sustainable way has been receiv- 
ing growing attention in global policy and in literature (Berkes, 2009; Borrini et al, 2004) during recent decades. Their contribution has been also seen in combining their knowledge and experience with contemporary science and technology and sharing it through their participation in co-management and governance processes (Borrini et al, 2004).

Of course, local community is not a homogenous entity with unified needs and characteristics. This was seriously taken into consideration while developing the methodology of assessment of community involvement in PA governance in the Dinaric region, which comprises perspectives of diverse community groups and stakeholders, as well as of representatives of PA management constituencies, shared through separate and joint meetings in each of the involved protected areas.

Within this methodology approach, community involvement refers to "processes of active participation in planning, decision-making and local development and respects variety of values, meets interests and needs of different groups from local community and stakeholders" (WWF Adria, 2017a, p. 3).

\section{Assessment of community involvement in protected area governance}

\section{Background}

The research was carried out under the framework of the project Protected Areas for Nature and People (PA4NP - 2015-2019), launched by WWF Adria, with the aim of performing an assessment of the current level of involvement of local communities and to provide recommendations for improvements of capacities needed for quality PA governance and for community development based on principles of sustainability. As planned by the project, the methodology ${ }^{2}$ should be developed and applied for continuous monitoring and improving of interactions between protected areas and communities in the Dinaric region, but can also be used in other parts of the world. While there is a number of tools developed previously to assess the management effectiveness which incorporated aspects of community involvement, there was not one which allows a detailed assessment of community interaction and identification of gaps as the basis for the preparation of a comprehensive capacity development plan that would lead to

\footnotetext{
2 The Community Involvement Assessment methodology has been developed by a team of four experts: Violeta
} Orlović Lovren, Serbia; Wilf Fenten, UK; Jana Kus Veenvliet, Slovenia; Richard Partington, UK. 
improvements of the current situation (WWF Adria, 2017). The project aimed to fill this existing gap and to support development of original assessment methodology, which would result in the creation of the "protected areas/community interaction index", with a set of criteria to help assess and rank of their interaction (WWF Adria, 2016).

"Parks Dinarides - network of protected areas of the Dinarides" (DAP) was officially established in 2014 as a result of WWF's "Dinaric Arc Parks" project, to facilitate experience exchange, development of mutual projects and promotion (WWF Adria, 2016). Above all, this association is responsible for the monitoring of interaction between PAs and communities and initiating capacity development programs for its members (parks and surrounding communities).

\section{Methodological approach}

The following principles incorporated into the project and in the overall work of the WWF were particularly considered while developing the assessment methodology: human rights based approach (right to information, to participation in decision making and to non-discrimination and equality) and sustainability (including all three pillars - the environmental, social and economic pillar) (WWF, 2017a).

A participatory approach has been applied not only in the development of assessment tools - through evaluation of indicators, collecting feedback from the pilot assessments and from assessors engaged - but also in its application - by organizing assessment through the workshops with opportunities for interaction between the community, the protected areas and experts on the spot (WWF Adria, 2017a). The overall purpose of this approach was to contribute to improving the relationships between community and PA staff, and to engage them in reflecting on existing opportunities and barriers.

The methodology uses a combination of a quantitative and qualitative approach and methods to assess interactions from the perspective of protected area representatives and local communities. The quantitative aspects comprise developing the scoring system ('index of interaction') to group protected areas on a scale of interaction with the community ranging from 1 to 5 ( 1 being the lowest); each of the levels corresponds to a rank defined by the Standard Ranking Criteria: from "little or no interaction" to "exemplary" level. Using a five-level scale for each of the questions in the assessment tools, it became possible to calculate sub-indices (for each individual field of performance for each protected area) and 
indices (for the entire performance of the protected area) as quantitative measures of interactions with the community (WWF Adria, 2017a). It also comprises a survey applied to the local community group in each of the research venues.

Qualitative aspects refer to methods applied during the research (facilitated discussion, interview), as well as to the validation and analysis of data.

Two research instruments have been developed and applied: questionnaire for local communities and for protected areas - including the same content of the questions with necessary modifications in its formulation. While filling in the questionnaires for community representatives was facilitated by assessors, the one for PA representatives was used as a kind of protocol for a structured interview, conducted again by the previously trained assessors.

The questions were developed along the seven sections which were identified as essential for community involvement:

1. Decision-making and decision-influencing

2. Management planning

3. Communication

4. Education

5. Social development

6. Economic development and

7. Equal rights and opportunities

In accordance with the criteria set up by the project team and shared with PA managers in advance, local community representatives were selected from the following groups:

- inhabitants from the territory of the protected area and its vicinity, as well as the stakeholders from the territory within or outside of the protected area borders;

- representatives of both non-public authority stakeholders (community-based organizations, cooperatives, NGOs, minority groups, clubs and other 'communities of interest') and pubic authority stakeholders (state agencies, research and education institutions, municipal or regional administration, etc.).

\section{Organization of the assessment}

This methodology was first applied between March and May 2017, in 66 Dinaric Arc protected areas (from Albania, Bosnia and Herzegovina, Croatia, Kosovo*, 
Macedonia, Montenegro, Slovenia and Serbia), which comprise $77 \%$ of the protected areas in the region. The lowest percentage of protected areas included in the assessment was in Kosovo (25\%), Slovenia (58\%) and Macedonia (75\%), while in Bosnia and Herzegovina and Montenegro all the planned protected areas were assessed (WWF Adria, 2017).

The coordination with protected areas involved in the assessment was carried out by the WWF Adria office and DAP, while PA managers were asked to select and invite stakeholders (in accordance with the above described criteria) and to organize meetings in jointly agreed local premises. Assessors were facilitating the assessment and providing reports with scores, as well as with quality feedback, using the protocol prepared in advance by the project team.

\section{Data processing}

Data collected during the first assessment was analysed both statistically and qualitatively. In this paper, we are providing an interpretation of the statistical analysis, covering key trends and in particular those findings related to education and capacity development. For that segment ("section") of the research, we also discuss findings based on qualitative analysis, at the level of all the PAs involved.

Within the quantitative analysis, descriptive statistics (means and standard deviations) for all indicators and countries (separately for estimations of representatives of protected areas and local communities, named here as "source"), were calculated. Univariate ANOVA (repeated measure) and bi-factorial ANOVA (mixed model) were used in order to find statistical differences. In addition, as a measure of statistic power, partial eta square correlations were added. Pearson linear correlations were used as a measure of concordance between estimations of protected area and local community representatives.

\section{Perceptions of community involvement in protected area governance in the Dinaric region - key trends and lessons}

Based on statistical analysis of the data concerning all the segments of PA governance, social development is on average the highest ranked 'section' (Figure 1). Education and capacity development as well as communication are next well-ranked aspects. According to both groups of participants in this research 
(protected area and local community representatives), economic development is underdeveloped, while management planning is the least developed field of their mutual engagement in the region. The lowest ranked fields of engagement, from the perspective of local communities, are equal rights and opportunities, as opposed to economic development and management planning, as noted by PA representatives.

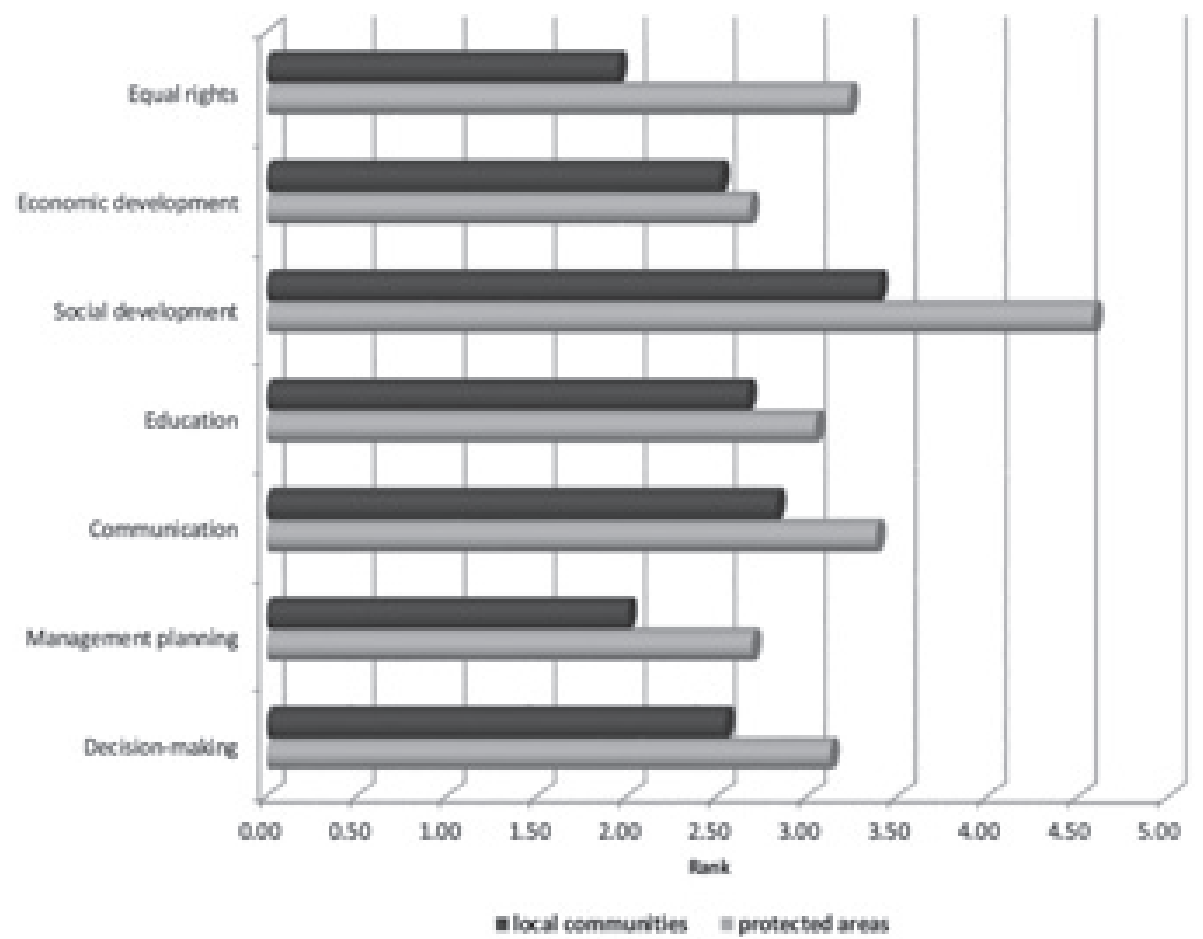

Figure 1: Perspectives of community involvement in PA governance by sections Source: WWF Adria, 2017

However, regardless of the assessment level, it is indicative from the presented trends that a gap exists both in highest ranked (social development) and the lowest ranked segments of community involvement (equal rights, management planning). Is there some considerable misunderstanding between the protected areas and the local communities? Or is information about these activities simply not available to everyone? When comparing trends in the perception of communication and decision making in some countries (Montenegro, Croatia), 
it becomes obvious that there is quite a similar gap in the perspectives of PA and LC in both segments. It leads to the conclusion that a lack of effective communication - at least with the groups who participated in this assessment - leads to weaknesses in the involvement of communities in decision-making, as a crucially important aspect of PA governance.

According to statistical analysis, protected area representatives tend to estimate their contribution to community engagement and development higher in all the parts of the Region and for all the sections comprised, when compared with the perceptions of local community groups. As shown in Table 1, there is a statistically significant difference between protected area (PA) and local community (LC) assessments in all the sections, except economic development (WWF Adria, 2017).

Table 1: Differences in scoring between PA and LC by sections

\begin{tabular}{l|c|c|c|c|c|c|c}
\hline & \multicolumn{2}{|c|}{ Protected areas } & \multicolumn{2}{l|}{ Local communities } & & \\
& Mean & $\begin{array}{c}\text { Std. } \\
\text { Deviation }\end{array}$ & Mean & $\begin{array}{c}\text { Std. } \\
\text { Deviation }\end{array}$ & F (1,73) & Sig. & $\begin{array}{c}\text { Partial Eta } \\
\text { Squared }\end{array}$ \\
\hline \hline Decision-making & 3.122 & .7394 & 2.541 & .6660 & 26.818 & .000 & .269 \\
$\begin{array}{l}\text { Management } \\
\text { planning }\end{array}$ & 2.689 & 1.2042 & 2.000 & .9363 & 15.471 & .000 & .175 \\
$\begin{array}{l}\text { Communication } \\
\text { Education }\end{array}$ & 3.378 & .6127 & 2.824 & .6050 & 39.218 & .000 & .349 \\
$\begin{array}{l}\text { Social } \\
\text { development }\end{array}$ & 3.041 & .8348 & 2.662 & .6880 & 11.143 & .001 & .132 \\
$\begin{array}{l}\text { Economic } \\
\text { development }\end{array}$ & 2.581 & .6195 & 3.392 & .7180 & 138.016 & .000 & .654 \\
Equal rights & 3.230 & .7957 & 2.514 & .7261 & 2.628 & .109 & .035 \\
\hline
\end{tabular}

Source: WWF Adria, 2017

In the context of research, the education and capacity development 'section' refers to: non-formal learning programmes provided by protected areas - by them or in collaboration with local and other resources (NGOs, institutions, experts, etc.); participation of protected area staff in formal education programs (guest lecturers or joint projects in schools, serving as experimental or learning/ internship sites for students, etc.); support to community and visitor informal learning (provision of tailored-made promotion materials, events, specific learning experiences on the site, etc.). Capacity development refers both to efforts provided by a protected area for external audiences, as well as those directed towards their own staff and volunteers (WWF Adria, 2017). 


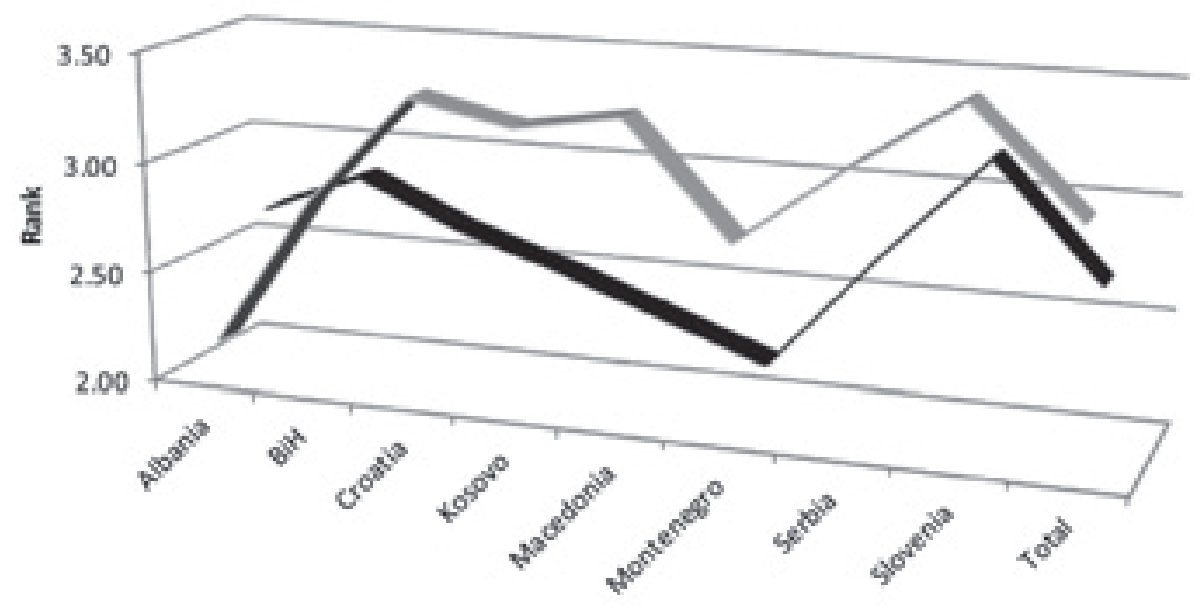

\section{a PA Education =LC Education}

Figure 2: Countries by education and capacity development

Source: WWF Adria,2017

As shown in Figure 2, education and capacity development have been assessed lower by LC than by PA - except in Albania (MPA:MLC = 2,16:2,66) and Bosnia and Herzegovina (MPA:MLC= 2,85:2,85) in the entire region. Such a perception of local community in the majority of areas might have roots either in the lack of existing programs and institutional solutions (engagement of the staff in charge, long-term education and capacity development planning, etc.) in protected areas or in the limited access to information about the programmes (WWF Adria, 2017). In some cases, as revealed from the quality analyses of the content of discussions at the workshops, it is probably resulting from the lack of programs tailored to the local community needs.

Similarity in perceptions found in the field of management planning and economic development in countries with significantly different levels of economic development (like Slovenia and Albania) may be slightly confusing. However, bearing in mind that in these countries we also found a close gap between the two groups in the field of communication, it appears as though we face the same rule again: with better communication there is better perception of collaboration in other relevant fields, as well. Also, having in mind a significantly different level of exposure to contemporary European and global standards in those countries, we may assume that an unequal level of understanding of the concepts of govern- 
ance and sustainability might have contributed to the satisfaction of communities even when PA management doesn't meet all the requirements.

The above presented and discussed tendencies have been selected from wider research results in order to focus on the key gaps in perceptions and understanding emerging between communities and protected areas in the Dinaric region. Based on that, a capacity development program was recommended by the Project team, as a guideline to communities and parks, for finding the best ways to meet needs - sometimes quite different and in some aspects very similar. Among the common needs, there are certainly those related to social development, management planning and economic development - whose meaning should be further clarified, negotiated and agreed among all the actors, so that they could be implemented in accordance with global standards and local interests. The huge gap in perspectives between the two groups of equal rights in terms of its integration in policy and in practice, in particular in the less developed parts of the region, needs not only awareness rising, but also interventions on a systemic level in each particular country and protected area organization.

As demonstrated by examples and experiences collected through the discussions on the sites, it is clear that communities and protected areas, within and between countries, can learn a lot from one another, sharing common challenges and needs even when coming from quite different environments. To start with - regarding the best models of mutual communication, which seems as crucially important for the (perspectives of) collaboration in all the other, interrelated, aspects of PA management and governance - and for community life.

\section{Conclusions}

Turbulent social, political and economic developments influencing Western Balkans in recent decades are shaping specifically not only opportunities to overcome environmental challenges, but also the ways sustainability is perceived and integrated in local development. In the Dinaric region, as elsewhere, relations between communities and protected areas are tackling questions of power, distance between people and nature and abilities to understand, reflect and act upon different needs and possibly common interests. Trusting that this power is not and shouldn't be in the hands of one participant, be that protected area or local authority, community or the state, the methodology for assessment of interactions between the community and protected areas was made to address perspectives of as many actors of this process as possible. It was designed 
to assure that there is participation in place throughout all the phases of the research - from preparation, through conducting to evaluation of results. In such a design, scoring and quantitative measures serve mainly as a guidance to understanding commonalities existing along the 'sections' of PA governance or within the group, protected area, country etc., while quality inputs and reflections are used to better understand its specific connotation, origins or possibilities to deal with. In that way, the analysis of entire collected material also grows into intensive learning process. Having in mind contributions made by participants and assessors in this process- through scoring, discussions and the feedback, we might consider it as a kind of the 'action research' initiative, and its results as a joint outcome, analysed and transferred by the project team into the recommendations for improvements.

In that sense, assessment workshops may be seen as a learning experience for all participants, that might even bring 'disorienting dilemmas' for some. However, if stopped at that level, this process will hardly contribute to closing the gap in perspectives and collaboration of communities with protected areas. If a transformation of perspectives is to take place, it needs to be carefully facilitated and supported in various ways. The responsibility of the Parks Dinarides Association as the key facilitator in this process should be shared with facilitators from countries or communities who show understanding of sustainability and adult learning, as well as with protected areas as mentors (when they have the best practice to share) or mentees (when they take the opportunity to learn from community members, experts or from other parks). For the success of all those actions, policy support and incentives should be provided in each part of the Region and in all the aspects of implementation of sustainable development concept through PA governance.

Transformation of the role of citizens in democratic processes, as well as the integration of sustainability in education and protected area management bring the chance to rethink the ways adult education may respond to the new and diverse needs. Beginning 'from where people are' and what they feel, think or can do about (concepts, policy, practice) is certainly the first step in the potential transformation towards more developed capacities and collaboration. 


\section{References}

Andrade, G. S., \& Rhodes, J. R. (2012). Protected areas and local communities: An inevitable partnership toward successful conservation strategies? Ecology and Society, $17(4)$.

Berkes, F. (2009). Evolution of co-management: Role of knowledge generation, bridging organizations and social learning. Journal of Environmental Management, 90, $1692-1702$.

BlewitT, J. (2006). The Ecology of Learning: Sustainability, Lifelong Learning and Everyday Life. London, Sterling, VA: Earthscan.

Bonnett, M. (2002). Education for Sustainability as a Frame of Mind. Environmental Education Research, 8(1), 9-20.

Borrini-Feyerabend, G., Kothari, A., \& Oviedo, G. (2004). Indigenous and Local Communities and Protected Areas: Towards Equity and Enhanced Conservation. Gland, Cambridge: IUCN.

Clover, D., Jayme, B. D. O., Follen, Sh., \& Hall, B. (2010). The Nature of Transformation: Environmental Adult Education. Victoria: University of Victoria.

Cranton, P. (2002).Teaching for Transformation. In J. M. Ross-Gordon (Ed.). Contemporary Viewpoints on Teaching Adults Effectively, 93, 63-73. San Francisco: Jossey - Bass.

D. Kapitulčinová, J. Dlouhá, A. Ryan, J. Dlouhý, A. Barton, M. Mader, D. Tilbury, I. Mulà, J. Benayas, D. Alba, C. Mader, G. Michelsen, K. Vintar Mally (Eds.). (2015). UE4SD. Leading Practice Publication: Professional development of university educators on Education for Sustainable Development in European countries. Prague: Charles University.

Dovers, S., Feary, S., Martin, A., McMillan, L., Morgan, D., \& Tollefson, M. (2015). Engagement and participation in protected area management: who, why, how and when? In G. L. Worboys, M. Lockwood, A. Kothari, S. Fearyand and I. Pulsford (Eds.). Protected Area Governance and Management (pp. 413-440). Canberra: ANU Press.

Dudley, N., Ali, N., \& MacKinnon, K. (2017). Protected areas helping to meet the Sustainable Development Goals. Natural solutions. Retrieved from https://www. iucn.org/sites/dev/files/natural_solutions_-_sdgs_final_2.pdf).

Hajer, M., Nilsson, M., Raworth, K., Bakker, P., Berkhoutb, F., DeBoer, Y., Rockström, J., Ludwig, K. \& KoK, M. (2015). Beyond Cockpit-ism: Four Insights to Enhance the Transformative Potential of the Sustainable Development Goals. Sustainability 7, 1651-1660.

Howard, P. (2012). Who Will Teach The Teachers? Reorienting Teacher Education for the Values of Sustainability. In K. A. Battels \& K. A. Parker (Eds.). Teaching Sustainability / Teaching Sustainably (pp. 150-159). Sterling, Virginia: Stylus.

IonTJA, A. (2013). Guidelines for the development of a participatory management of protected areas in the Carpathian Ecoregion. In M. Getzner \& M. Jungmeier (Eds.). Protected Areas in Focus: Analysis and Evaluation (pp. 34-39). Klagenfurt: Verlag Johannes Heyn. 
Jensen, J. (2014). Learning Outcomes for Sustainability in the Humanities. In W. P. Boring \& W. Forbes (Eds.). Teaching Sustainability (pp. 23-38). Nacogdoches: Stephen Austin State University Press.

Leal Filho, W., Raath, S., Lazzarini, B., Vargas, V. R., de Souza, L., Anholon, R., Quelhas, O.L.G., Haddad, R., Klavins, M., \& Orlovic, V. L. (20 i 8). The role of transformation in learning and education for sustainability. Journal of cleaner production, 199, 286-295.

Lockwood, M., Worboys, G., \& Kothari, A. (Eds.). (2012). Managing protected areas: a global guide. Routledge.

Mezirow, J. (1991). Transformative Dimensions of Adult Learning. San Francisco: JosseyBass.

Newman, M. (2012). Calling Transformative Learning into Question: Some Mutinous Thoughts. Adult Education Quarterly, 62(1), 36-55.

Orlovic Lovren, V. (2013). Learning and Capacity Development for Protected Area Management. In M. Getzner \& M. Jungmeier (Eds.). Protected Areas in Focus: Analysis and Evaluation (pp. 87-97). Klagenfurt: Verlag Johannes Heyn.

SarkKi, S., Rantala, L., \& Karjalainen, T. P. (2015). Local people and protected areas: identifying problems, potential solutions and further research questions. Int. J. Environment and Sustainable Development, 14(83), 299-314.

Scotт, W., \& Gough, S. (2003). Sustainable Development and Learning: Framing the Issues. London and New York: Routledge Falmer.

Sipos, Y., Battisti, B., \& Grimm, K. (2008). Achieving transformative sustainability learning: engaging head, hands and heart. International Journal of Sustainability in Higher Education, 9(1), 68-86.

UN. (2015). Transforming Our World: The 2030 Agenda for Sustainable Development. Retrieved from: www.sustainabledevelopment.un.org

UNESCO. (2017). Education for Sustainable Development Goals: Learning objectives. Retrieved from https://unesdoc.unesco.org/ark:/48223/pf0000247444

UNESCO. (2014). Aichi Nagoya Declaration on Education for Sustainable Development. Retrived from: https://sustainabledevelopment.un.org/content/docu ments/5859AichiNagoya_Declaration_EN.pdf

Vandenabeele, J., Reyskens, P., \& Wildemeersch, D. (2011). Diverse views on citizenship, community and participation: Exploring the role of adult education research and practice. European journal for Research on the Education and Learning of Adults, 2, 193-208.

Van Poeck, K., \& VAndenabeele, J. (2014). Education as a response to sustainability issues. European Journal for Research on the Education and Learning of Adults, 5, 221-236.

Vulfolk, A., Hjuz, M., \& Volkap, V. (2014). Psihologija u obrazovanju. Beograd: Clio.

WALs, A. E. J. (2015). Beyond Unreasonable Doubt. Inaugural address held upon accepting the personal Chair of Transformative Learning for Socio Ecological Sustainability at Wageningen University. Retrieved from: https://arjenwals.files.wordpress. com/2016/02/8412100972_rvb_inauguratiewals_oratieboekje_v02.pdf 
Wildemeersch, D., \& Fejes, A. (2018). Citizenship and the crisis of democracy: What role can adult education play in matters of public concern? European Journal for Research on the Education and Learning of Adults, 9(2), 133-137.

Worboys, G. L., Lockwood, M., Kothari, A., Feary, S., \& Pulsford, I. (Eds). (2015). Protected Area Governance and Management. Canberra: ANU Press.

WWF Adria. (2016). Protected areas for nature and people. Program Application.

WWF Adria. (2017). Capacity development Plan - Report from the Community involvement assessment, prepared by: Wilf Fenten, Jana Kus, Violeta Orlovic Lovren and Richard Partington.

WWF Adria. (2017a). Methodology Manual-Report from the Community involvement assessment, prepared by Violeta Orlovic Lovren, WilfFenten, Jana Kus, and Richard Partington.

Violeta Orlović Lovren ${ }^{3}$

Filozofski fakultet, Univerzitet u Beogradu

\section{Učenje za održivost putem uključivanja zajednice u upravljanje zaštićenim područjima}

Apstrakt: U ovom radu se razmatra uključivanje zajednice u upravljanje zaštićenim područjima kao moguća prilika za učenje, razmenu znanja i mogućnost donošenja odluka, kao i zarad unapređenja održivosti, počev od lokalnog, preko regionalnog i nacionalnog, pa sve do globalnog nivoa. Osim kratkog pregleda teoretskih pristupa i pristupa politika relevantnih za učenje sa ciljem unapređenja održivosti lokalne zajednice, ovaj rad obuhvata i sekundarnu analizu rezultata empirijskog istraživanja uključenosti zajednice u upravljanje zaštićenim područjima. Ovo istraživanje je obavljeno u okviru projekta „Zaštićena područja za prirodu i ljude“ (Protected Areas for Nature and People), koji je sprovela organizacija WWF Adria. Korišćena metodologija obuhvata kombinovani kvalitativni i kvantitativni pristup. Rezultati istraživanja jasno ukazuju na to da postoji raskorak u proceni između predstavnika zaštićenih područja i predstavnika zajednice, kao i nedvosmislena potreba za poboljšanjima u međusobnoj komunikaciji i saradnji. Potrebe i prilike za učenje u tom procesu razmatraju se na osnovu tih saznanja u okviru lokalnog konteksta i globalnih razvojnih trendova.

Ključne reči: učenje, održivost, lokalna zajednica, zaštićeno područje, upravljanje.

\footnotetext{
${ }^{3}$ Dr Violeta Orlović Lovren je vanredni profesor na Filozofskom fakultetu Univerziteta u Beogradu.
} 